UDC: $811.161 .2 ’ 2161.2$

DOI: https://doi.org/10.24195/2414-4665-2017-4-23

\author{
Anzhela Budnik, \\ PhD (Candidate of Pedagogical Sciences), associate professor, \\ Department of Slavic Linguistics, \\ South Ukrainian National Pedagogical University named after K. D. Ushynsky, \\ 26, Staroportofrankivska Str., Odessa, Ukraine
}

\title{
LANGUAGE PORTFOLIO IN TEACHING UKRAINIAN AS A FOREIGN LANGUAGE
}

The choice of the research topic is determined by several factors: the necessity to find effective means of evaluating various kinds of work, the necessity to acquire and organise necessary knowledge by international students themselves in order to be able to solve communication problems according to situations. The paper aims to provide theoretical substantiation of the model of language portfolio used as a complementary tool for monitoring and assessment of international students' academic performance when learning Ukrainian as a foreign language. Research methods involved consideration of methodological and psycho-pedagogical literature, legal documents, their analysis and synthesis; generalisation of scientific developments, lesson observation, pedagogical modelling, sociological methods. A language portfolio of an international students consists of contents, the portfolio itself with the list of its principal elements, introduction with clear formulated aim and objectives, brief description of the language portfolio, a student's self-analysis and self-evaluation of the work done. The use of language portfolio method in work with international students is quite effective, as it develops critical and creative thinking, capacity for self-analysis, ability to use scientific literature, choose authentic texts corresponding to a communicative aim.

Keywords: European Language Portfolio, language portfolio, components of a language portfolio, Common European Framework of Reference for Languages, levels of language proficiency, kinds of language activity, principles of communicative teaching, reflection, Ukrainian as a foreign language.

\section{Introduction}

Nowadays Ukraine has become quite a popular state for foreigners to obtain higher education. First of all, it demonstrates the significance of education, the development of socio-cultural and communicative, linguistic cross-cultural and discursive competencies, methods of implementing new educational technologies into the educational process, the use of information and communication technologies in teaching foreign students at different stages of university and pre-university training. New information and technical changes in the society, realisation of the fact that the indicator of the high level of academic achievements at all levels of education is not reproduction of the information acquired during training at the university, but knowledge and skills that are necessary for the successful implementation of life and professional strategies both during training and after graduation - all these factors cause the need for new approaches to teaching and evaluating foreign students' knowledge with the purpose of searching and using new forms and methods. Recently, European standards of teaching, joint training programmes, new educational technologies, specific teaching methods has been more and more often implemented in the educational process of our country. Considerable attention should be paid to creating favourable conditions for students' and teachers' academic mobility, which contributes to the integration of domestic universities in the global research and educational process. For this very reason, the issue of reforming and upgrading training programmes in accordance with European stand- ards, whose implementation will develop domestic universities' competitiveness in the European education space, is becoming more and more topical. Currently, traditional system of knowledge assessment limits the development of behavioural skills, core competencies, the ability to respond according to communication tactics and strategies peculiar to today's higher education and future profession.

The choice of the research topic is determined by several factors: the necessity to find effective means of evaluating various kinds of work, the necessity to acquire and organise necessary knowledge by international students themselves in order to be able to solve communication problems according to situations. In the universities of Ukraine, foreign citizens are educated in the official language, which is foreign for them. In the South Ukrainian National Pedagogical University named after K. D. Ushynsky international students obtain their degrees according to the integrated curricula in Russian and Ukrainian as foreign languages. Studying the language by international students majoring in non-philological specialities is the basis for professional training in the chosen speciality, and the language itself is a means of studying; so, the main task of the language classes is to develop the students' language skills and abilities in the communication forms, which their learning activity is based on. The major aim is the communicative one, since learning and educational aims are implemented on condition that the students achieve a certain level of proficiency. It is achieved by means of the formation of language and 
speech skills required by the students in all types of speech activities (reading, listening, speaking, writing), providing them with the opportunity to communicate in the Ukrainian-language environment (education, life, culture) and obtain the speciality [2, p. 4, 6].

According to the Common European Framework of Reference for Languages (CEFR), six levels of foreign language qualifications can be distinguished: breakthrough or A1, waystage or A2, threshold or B1, vantage or $\mathrm{B} 2$, effective operational proficiency or $\mathrm{C} 1$, and mastery or $\mathrm{C} 2[10 ; 4]$. These levels were developed by the Association of Language Testers in Europe (ALTE) and cover all the levels of language proficiency, from the basic level to fluency in a language. All the study guides for any European language as well as methodology guidelines for learning certain topics or writing research papers, reference books, dictionaries, and tests are based on these levels. The system of mastering Ukrainian as a foreign language has been developed under the auspices of the Council of Europe according to the guidelines titled "Modern Languages: Learning, Teaching, Assessment. A Common European Framework of Reference. Council for Cultural Co-operation, Educational Committee, Strasbourg, 1996" and ALTE recommendations.

Various aspects of methods of teaching foreign citizens were considered by numerous domestic and foreign scholars including Ye. Basnin, T. Dementieva, N. Bulhakova, S. Vyshniakov, I. Skutelchuk et al. However, their study area was focused primarily on the necessity to understand and analyse the features of international students' adaptation, on the specific character of organisation of teaching various disciplines at preparatory departments and during self-directed learning. The issue of the formation of international students' creative capabilities, eliciting their creative potential is of interest, but currently remains understudied. In this regard, in it reasonable to mention language portfolio method (V. Zagvozdkina, I. Kalmykova, M. Ostrenko, T. Novikova, H. Barrett, E. Book, D. Niguidula, D. Sweet), which has come into active use in schools, but is rarely used in work with students. The aspects of development and use of language portfolio in teaching foreign languages at comprehensive educational institutions were considered by N. Almazova, I. Bezhenar, N. Halskova, D. Isaieva, O. Karpiuk, L. Labazina, Z. Nykytenko, I. Osadcha, Yu. Pasov, Ye. Polat, I. Yudina, L. Yahenich, P. Aarts, R. Broeder, A. Dobson, F. Goullier, P.McLagan, D. Little, O’Malley J. Michael, M. Muller, T. Oliinyk, P. Pavlow, R. Perclova, L. Pierce, R. Scharer, J. Trim. They provided theoretical substantiation of some principles of effective use of language portfolio for assessing command of the English language taking into account innovations in education, modernisation of the content of education, forms and methods of teaching foreign languages. As for students, most research works deal with the use of the European language portfolio for training future economists (S. Nikolaieva, O. Plokhotniuk, N. Yahelska) or lawyers (L. Yahenich). Despite the sufficient theoretical background for a foreign language portfolio, the issues of substantiation, development and use of the Ukrainian language portfolio have drawn researchers' attention fairly recently (O. Proselkova, I. Dzhuhan, N. Morhunova), and the use of portfolio for Ukrainian as a foreign language when training international students at Ukrainian universities is almost understudied.

The paper aims to provide theoretical substantiation of the model of a language portfolio, which is used as a complementary tool for monitoring and assessment of international students' academic performance when learning Ukrainian as a foreign language. According to the aim, the following tasks have been defined: to generalise experience of using portfolio method by specialists from other countries, to outline conditions for efficient use of this method in assessment of knowledge and abilities of international students learning Ukrainian as a foreign language, to test experimentally the use of the suggested language portfolio method as information and communicative technology in teaching Ukrainian.

Research methods: consideration of methodological and psycho-pedagogical literature, legal documents, their analysis and synthesis with the purpose of defining conceptual principles of the research; generalisation of scientific developments, lesson observation, pedagogical modelling, sociological methods.

\section{Discussion}

The ways of using a portfolio in higher educational institutions of our country are currently understudied (this issue has been considered in details earlier) [1]. As noted before, there are a great number of definitions for the notion "portfolio". First of all, it is defined as a new approach to teaching, which facilitates the formation of entirely different interaction between a teacher and a student (compared to traditional teaching methods), which is characterised by new tasks and knowledge assessment criteria [2, p. 573]. The primary function of the portfolio is presentation of all the variety of one's capabilities. Pedagogical and didactic aspects of portfolio are focused not on general knowledge and abilities, but knowledge and abilities within the scope of a certain topic, unit; on combination of qualitative and quantitative assessment; on the formation of social, cultural and linguistic competencies and, accordingly, boosting students' confidence.

The European Language Portfolio was developed and tested by the Language Policy Division of the Council of Europe in Strasbourg in 1998-2000 with the purpose of standardisation of requirements to foreign language learning by citizens of European countries and promotion of the development of cultural and linguistic diversity. In general, the portfolio has been tested in more than 15 countries of the European Union, but in Ukraine it was introduced only in 2003. European Language Portfolio includes three levels of language proficiency and linguistic competences - A, B, C. These levels characterise the main kinds of language activities: understanding (listening for oral speech and reading for written speech); speaking (a monologue as a form of 
productive speaking and a polylogue as a form of interactive speaking); writing as a separate productive kind of language activities. The Common European Framework of Reference for Languages offers three mandatory components of a language portfolio: Language Passport, Language Biography, and Dossier $[3 ; 4 ; 5]$. It is worth noting that the European Language Portfolio presents direct implementation of European language standards, i.e. practical objective statement and assessment of foreign language proficiency using descriptors developed by the Council of Europe in accordance with Common European scale of levels.

It is noted in CEFR that introduction of language portfolio serves to reduce formal character of assessment process; based on additional information about foreignlanguage learning experience, it will contribute to more objective and reasonable assessment of knowledge, realistic correlation of regional and national grading systems with international standards [10].

On the basis of N. Koriakovtseva's definition (which is the most appropriate and precise, in our opinion), we consider a language portfolio as a packet of learning materials, which is the product of a student's activity in terms of learning a foreign language, which provides both a teacher and a student with an opportunity to review and evaluate (either independently or together) the scope of work done or a student's achievements in learning a foreign language and culture, dynamics of mastering a foreign language in various aspects [6].

It is important that the process of composing a language portfolio is based on the principles of communicative teaching proposed by Ye. Passov: the principle of teaching process focus on speaking (during practical lessons the language learned is used in practice in order to achieve a communicative aim), the principle of individualisation of learning (a learner's personality is taken into account, namely his/her capabilities, ability for reflection, abilities related to learning and communicative activity), the principle of functionality (selecting vocabulary and instructional material in accordance with a communicative aim), the principle of contextuality (teaching Ukrainian involves immersion in communicative situations and problems that are close to real life), the principle of novelty (subject, object, conditions, and aim of communication are constantly changing in the flow of communication) [7]. Therefore, the Ukrainian language is taught with minimum use of intermediate language or a learner's native language (except for teaching phonetics, speech apparatus, and correct pronunciation).

According to the above-listed principles of communicative teaching, a language portfolio consists of individual creative works prepared by international students, language material and authentic texts related to the topics learned. The material is chosen by a learner him/herself. For instance, when learning scientific prose style in the fourth year of study, students collect the samples of document layout, business correspondence, clichés for telephone conversations, set expressions used when writing scientific papers and proceedings, resumes, abstracts, etc. The purpose of such a portfolio is helping international students with acquisition, systematisation, generalisation, and memorisation of language material (both grammar and vocabulary). The main objectives of the language portfolio are as follows: practical mastering of the system and principles of functioning of Ukrainian as a foreign language in terms of using them in accordance with a communicative aim and situation, work with authentic texts, search and choice of necessary information. The main functions of the portfolio are supporting international students' academic motivation and developing the skills of their reflective and evaluation activities.

Due to the fact that the language portfolio is composed and checked as part of teaching the subject "The Ukrainian Language" for international students, the structure and content of works may vary depending on students' language competence, peculiarities of their grouping, etc. Let us consider the structure and content of the language portfolio through the example of the subject "The Ukrainian Language" for foreign citizens who learn Ukrainian at non-philological faculties of Ukrainian universities during 702 academic hours. The discipline covers 14 key topics (The city of a student's study, A student's hometown, Higher educational institution of a student, Future profession of a student, Ukraine (state and economic structure), Educational system of Ukraine, Educational system of a student's native country, Kyivan Rus, Kyiv is the capital of Ukraine, Capital of a student's native country, Taras Shevchenko is a poetic symbol of Ukraine, Ukrainian traditions and customs, Traditions and customs of a students' native country) and 8 additional topics (On the history of Slavic people, World economic system, Integration of Ukraine into the European educational environment, Bologna process and educational system of Ukraine, Global challenges of the mankind, Prominent Ukrainian scientists, Ukraine through the eyes of a foreigner, Young people all over the world). Accordingly, the language portfolio consists of 22 units, each of them corresponds to a certain topic of the discipline. Every unit (topic) includes relevant vocabulary, a list of clichés, grammatical structures, results of projects, relevant authentic material, supporting information, etc.

Language portfolio of an international student at its final stage includes contents, the portfolio itself with the list of its principal elements, introduction with clear formulated aim and objectives, brief description of the language portfolio, self-analysis and self-evaluation of the work done. It can be concluded that the language portfolio is the tool of self-evaluation and an international student's own cognitive and creative experience, reflection of his/her learning activity, a set of independent works, which consists of three parts - language passport (demonstrates communicative and non-communicative competence, information about cross-cultural contacts), lan- 
guage biography and dossier. Tables for self-evaluation are the integral part of an international student's language portfolio. Working partnership with the teacher contributes to the formation of the students' skills of scientific communication. It is reasonable to allot a separate unit titled "Comments and Suggestions" for the teacher to comment on the student's work. However, it should be kept in mind that it is up to the student to decide what kind of material he/she supplements the portfolio with. The moment of self-determination is of great importance as long as it is the prerequisite for enhancement of the student's self-responsibility in relation to learning, for independence in the organisation of learning.

For creating any kind of a portfolio, it is important for a teacher to ponder over the tasks suggested for an international student to perform, while the student should reflect upon methods and sequence of his/her actions. An international student should analyse if the way solving the given problem has been effective, correct and precise; how effectively he/she has organised his/her work. As noted by I. Fatieieva, "I am analysing my own learning to find out how I learn" [9, p. 527].

It is incredibly difficult to assess the language portfolio, as long as it is necessary to assess not only the product of a student's work, but how he/she has been working to achieve the result, what he/she has understood or has to understand. If a student collects his/her works on a certain subject on a regular basis, a teacher or even a student him/herself will be able to follow up his/her progress. Assessment of the portfolio consists of two parts: assessment of paper projects as a part of the portfolio and oral presen-

\section{REFERENCES}

1. Budnik, A. \& Khyzhniak, I. (2016). Linghvodydaktychni zasady vykorystannia metodu portfolio $\mathrm{v}$ navchanni inozemnykh studentiv [Linguodidactic principles of portfolio method use in teaching foreign students]. Ucrainica VII. Současná Ukrajinistika. Problémy jazyka, literatury a kultury - Contemporary Ukrainian studies. Issues of language, literature and culture. (pp. 572-578) [in Ukrainian].

2. Trostynska, O., \& Ushakova, N. (Eds.). (2009). Yedyna typova navchalna prohrama $z$ ukrainskoi movy dlia studentiv-inozemtsiv osnovnykh fakultetiv nefilolohichnoho profiliu vyshchykh navchalnykh zakladiv Ukrainy III-IV rivniv akredytatsii [Integrated typical curriculum in Ukrainian for foreign students studying at non-philological faculties of higher educational institutions of Ukraine]. Kyiv: NTUU "KPU” [in Ukrainian].

3. Nikolaiev, S. (Ed.). (2003). Zahalnoievropeiski rekomendatsii z movnoi osvity: vyvchennia, vykladannia, otsiniuvannia [Common European framework of reference for languages: learning, teaching, assessment]. Kyiv: Lenvit [in Ukrainian].

4. Nikolaieva, N., Bondarieva, N., Demianiuk, A. et al. (Eds.). (2003). Zahalnoosvitnii standart $z$ ukrainskoi movy yak inozemnoi (rivni: A1, A2; B1, B2; C1) [General educational standard for Ukrainian as a tation of the project. T. Novikova suggests assessment of written component of the portfolio on a scale from one to four and distinguishes the following criteria: having one's own point of view, establishing internal relations; the level of reasonability of the choice of material, argumentativeness of conclusions; the manner of information presentation (language, style, etc.); compliance with the requirements to the format of the works [8, p. 210].

The listed above criteria are typical, first of all, for paper projects included in the language portfolio. For the assessment of oral part of the portfolio, we have developed clear criteria and the form filled in after each student's presentation. The results of oral and written works performed by international students are summarised, and after that overall assessment is given. It should be kept in mind that assessment covers only students' knowledge and abilities within the scope of a certain topic or discipline, and how precise his/her evaluation of his/her own achievements is.

\section{Conclusions}

In our opinion, the use of the language portfolio method in work with international students is quite effective, as it develops critical and creative thinking, capacity for self-analysis, ability to use scientific literature, choose authentic texts corresponding to a communicative aim. However, this method cannot replace traditional teaching.

The issues of the stages the language portfolio development, comprehensive description of its parts and standardised system of its assessment are relevant for further research.

foreign language (levels A1, A2; B1, B2; C1)]. Retrieved from: http://old.mon.gov.ua/ua/activity/education/1410876247 / [in Ukrainian].

5. Ushakova, N., \& Dubichynskyi, V. (Eds.) (2011). Kontseptsiia movnoi pidhotovky inozemtsiv $u$ VNZ Ukrainy [The conception of language training of foreigners in Ukrainian Universities]. Vykladannia mov $u$ vyshchykh navchalnykh zakladakh osvity na suchasnomu etapi. Mizhpredmetni zviazky. Naukovi doslidzhennia. Dosvid. Poshuky: zbirnyk naukovykh prats. - The teaching of languages in higher educational institutions today. Intersubject links. Scientific research. Experience. Search: Collection of scientific papers, 19, 136-146 [in Ukrainian].

6. Koriakovtseva, N. F. (2002). Sovremennaya metodika organizatsii samostoyatelnoy raboty izuchaiushchikh inostrannyy yazyk [Modern methods of organizing independent work of foreign language learners]. Moscow: ARKTI [in Russian].

7. Passov, Ye. I. (2015). Teoriya metodiki. Inoyazychnoe obrazovanie: organizatsiya $i$ upravlenie [Theory of methodology. Foreign-language education: organization and management]. (Vols. 1). Lipetsk: Tipografiia [in Russian]. 
8. Novikova, T., \& Pinskaya, M. (Eds.). (2004). Portfolio v zarubezhnoy obrazovatelnoy praktike [Portfolio in foreign educational practice]. Voprosy obrazovaniya-Educational issues, 3, 201-238 [in Russian].

9. Fateyeva, I. A., \& Kanatnikova, T. (2012). Metod "portfolio" kak prioritetnaya innovatsionnaya tekhnologiya $\mathrm{v}$ obrazovanii: preyemstvennost mezhdu sredney shkoloy i vuzom [Portfolio method as a priority innovative technology in education: continuity between secondary school and university]. Molodoi uchenyi The young scientist, 12, 526-528 [in Russian].

10. Common European Framework of Reference for Languages: Learning, Teaching, Assessment. (n.d.).

\section{ЛІТЕРАТУРА}

1. Буднік А. Лінгводидактичні засади використання методу портфоліо в навчанні іноземних студентів / А. Буднік, I. Хижняк // Ucrainica VII Současná Ukrajinistika Problémy Jazyka, Literatury A Kultury. Sborník příspěvků $\mathrm{z}$ mezinárodní konference VIII. olomoucké sympozium ukrajinistů střední a východní Evropy (Olomouc 25-27.08.2016). - Olomouc. - St. 572-578.

2. Сдина типова навчальна програма з української мови для студентів-іноземців основних факультетів нефілологічного профілю вищих навчальних закладів України III-IV рівнів акредитації; [Затверджено МОН України]. - Ч. 3 / [за ред. О. Тростинської, Н. Ушакової]. - К. : НТУУ «КПІ», 2009. -50 c.

3. Загальноєвропейські рекомендації з мовної освіти: вивчення, викладання, оцінювання / [наук. ред. укр. видання доктора пед. наук, проф. С. Ніколаєва]. - К. : Ленвіт, 2003. - 273 с.

4. Загальноосвітній стандарт з української мови як іноземної (рівні: А1, А2; В1, В2; С1) [Електронний ресурс] / [укл. : Н. Ніколаєва, Н. Бондарєва, А. Дем'янюк та ін.]. - Режим доступу : http://old.mon.gov.ua/ua/activity/education/1410876247 /.

5. Концепція мовної підготовки іноземців у ВН3 України / Н. Ушакова, В. Дубічинський, О. Тростинська // Викладання мов у вищих навчальних закладах освіти на сучасному етапі. Міжпредметні зв'язки. Наукові дослідження. Досвід. Пошуки : збірник наукових праць. - Х., 2011. - №19. - С. 136146.
Strasbourg: Language Policy Unit. Retrieved from: www.coe.int/lang-CEFR [in English].

11. Oliinyk, T. (2005). Portfolio for young learners: objectives, structure and types. Reaching out to children: All-Ukrainian scientific and practical conference. Conference abstracts. (pp. 47-49). Horlivka: Vydavnytstvo Horlivskoho derzhavnoho pedahohichnoho instytutu inozemnykh mov [in English].

12. Savignon, S. J. (2002). Communicative language teaching: Linguistic theory and classroom practice, interpreting communicative language teaching. New Haven: Yale University Press [in English].

6. Коряковцева Н. Ф. Современная методика организации самостоятельной работы изучающих иностранный язык : Пособие для учителей / Н. Ф. Коряковцева. - М. : Изд-во АРКТИ, 2002. - 173 c.

7. Пассов Е. И. Теория методики. Иноязычное образование : организация и управление [Текст] / Е. И. Пассов. - Липецк : Типография, 2015. - Ч. 1. $548 \mathrm{c}$.

8. Портфолио в зарубежной образовательной практике / Т.Г. Новикова, М. А. Пинская, А. С. Пртученков, Е. Е. Федотова // Вопросы образования. - 2004. - №3. - С. 201-238.

9. Фатеева И. А. Метод «портфолио» как приоритетная инновационная технология в образовании: преемственность между средней школой и вузом / И. А. Фатеева, Т. Н. Канатникова // Молодой учёный. - 2012. - №12. - С. 526-528.

10. Common European Framework of Reference for Languages : Learning, Teaching, Assessment [Електронний ресурс]. - Режим доступу : www.coe.int/lang-CEFR.

11. Oliinyk R. Portfolio for young learners: objectives, structure and types / R. Oliinyk // Reaching out to children: Матеріали Всеукраїнської науковопрактичної конференції. - Горлівка : Видавництво Горлівського державного педагогічного інституту іноземних мов, 2005. - С. 47-49.

12. Savignon S. J. Communicative Language Teaching : Linguistic theory and classroom practice, interpreting communicative language teaching / S. J. Savignon. - New Haven : Yale University Press, 2002.

Анжела Олександрівна Буднік, кандидат педагогічних наук, доцент кафедри слов'янського мовознавства, Південноукраӥнський національний педагогічний університет імені К. Д. Уиинського, вул. Старопортофранківська, 26, м. Одеса, Украӥна

\section{ВИКОРИСТАННЯ МОВНОГО ПОРТФОЛІО У ПРОЦЕСІ ВИВЧЕННЯ УКРАЇНСЬКӦ̈ МОВИ ЯК ІНОЗЕМНОЇ}

Останнім часом частіше впроваджуються в освітній процес європейські стандарти навчання, інтегровані програми, нові освітні комунікативні технології, питомі форми та методи навчання тощо. Саме тому все ак- 
туальніше постає питання оновлення та модернізації навчальних програм у відповідності до загальноєвропейських стандартів, упровадження яких значно розширить конкурентоспроможність вітчизняних вищих навчальних закладів у порівнянні з європейськими. Обрана нами тема дослідження зумовлена необхідністю постійно знаходити дієві засоби оцінювання різних видів виконуваних робіт, необхідністю самостійно здобувати та систематизувати необхідні знання студентами-іноземцями, вміти розв'язувати комунікативні завдання відповідно до ситуацій. Метою нашої розвідки $є$ теоретичне обгрунтування моделі мовного портфоліо, яке використовується як додатковий засіб контролю та оцінювання іноземних студентів у процесі вивчення української мови як іноземної. Було використано такі методи дослідження: вивчення, аналіз та синтез науковометодичної та психолого-педагогічної літератури, нормативно-правових документів із метою визначення концептуальних положень дослідження; узагальнення наукових здобутків, педагогічне спостереження, педагогічне моделювання, соціологічні методи. У результаті проведення наукової розвідки було уточнено поняття мовне портфоліо, представлено його структуру, що складається зі змісту, власне портфоліо з перерахуванням його основних елементів, вступу з чітко сформульованою метою та завданнями, стислого опису мовного портфоліо, власного самоаналізу та самооцінювання виконаної роботи. Під час укладання мовного портфоліо враховуються принципи комунікативного навчання (принцип мовленнєвої спрямованості навчального процесу, принцип індивідуалізації навчання, принцип функціональності, принцип ситуативності, принцип новизни). Для створення будь-якого виду портфоліо важливими є роздуми не тільки над запропонованими студентові-іноземцю завданнями, але і його рефлексія щодо способів роботи, послідовності дій. Використання методу мовного портфоліо у роботі з іноземними студентами є доволі ефективним, оскільки розвиває критичне та творче мислення, здатність до самоаналізу, вміння користуватися науковою літературою, обирати автентичні тексти відповідно до комунікативної мети.

Ключові слова: Європейське мовне портфоліо, мовне портфоліо, компоненти мовного портфоліо, Загальноєвропейські Рекомендації з мовної освіти, рівні володіння іноземною мовою, види мовленнєвої діяльності, принципи комунікативного навчання, рефлексія, українська мова як іноземна.

Submitted on April, 4, 2017 